\title{
Fibroblast Proliferation and Migration in Wound Healing by Phytochemicals: Evidence for a Novel Synergic Outcome
}

\author{
Roberta Addis ${ }^{*}$, Sara Cruciani ${ }^{*}$, Sara Santaniello², Emanuela Bellu² ${ }^{2}$ Giorgia Sarais ${ }^{3}$, Carlo Ventura ${ }^{4}$, \\ Margherita Maioli2,4,5, ${ }^{\bowtie}$, Giorgio Pintore ${ }^{1}$ \\ 1. Department of Chemistry and Pharmacy, University of Sassari, Via F. Muroni $23 / b, 07100$, Sassari, Italy; \\ 2. Department of Biomedical Sciences, University of Sassari, Viale San Pietro 43/B, 07100 Sassari, Italy; \\ 3. Department of Life and Environmental Sciences, University of Cagliari, Via Ospedale 72, 09124 Cagliari, Italy; \\ 4. Laboratory of Molecular Biology and Stem Cell Engineering, National Institute of Biostructures and Biosystems - Eldor Lab, Innovation Accelerator, \\ Consiglio Nazionale delle Ricerche, Bologna, Italy. \\ 5. Center for Developmental Biology and Reprogramming (CEDEBIOR), Department of Biomedical Sciences, University of Sassari, Viale San Pietro 43/B, \\ 07100 Sassari, Italy \\ 6. Istituto di Ricerca Genetica e Biomedica, Consiglio Nazionale delle Ricerche (CNR), Monserrato, 09042 Cagliari, Italy \\ *Equal contributors \\ $\triangle$ Corresponding author: mmaioli@uniss.it; tel +39-079228277
}

() The author(s). This is an open access article distributed under the terms of the Creative Commons Attribution License (https://creativecommons.org/licenses/by/4.0/). See http:/ /ivyspring.com/terms for full terms and conditions.

Received: 2020.01.15; Accepted: 2020.03.18; Published: 2020.04.07

\begin{abstract}
Wound-healing is a dynamic skin reparative process that results in a sequence of events, including inflammation, proliferation, and migration of different cell types as fibroblasts. Fibroblasts play a crucial role in repairing processes, from the late inflammatory phase until the fully final epithelization of the injured tissue. Within this context, identifying tools able to implement cell proliferation and migration could improve tissue regeneration. Recently, plants species from all over the world are coming out as novel tools for therapeutic applications thanks to their phytochemicals, which have antioxidant properties and can promote wound healing. In this paper, we aimed at investigating antioxidant activity of waste extracts from different medicinal plants, endemic of the Mediterranean area, on fibroblast proliferation and wound healing. We determined the amount of total phenols and anti-oxidant activity by ABTS assay. We then evaluated the cytotoxicity of the compounds and the proliferative capabilities of fibroblasts by scratch assay. Our results showed that waste extracts retain antioxidant and regenerative properties, inducing tissue re-establishment after environmental stress exposure. Taken together, our findings suggest that waste material could be used in the future also in combinations to stimulate wound healing processes and antioxidant responses in damaged skin.
\end{abstract}

Key words: cellular mechanisms, cell proliferation, tissue regeneration, antioxidants, natural molecules, oxidative stress

\section{Introduction}

Wound-healing is a dynamic process, which, following skin injury, arises through a sequence of events, including inflammation, proliferation, and migration of different cell types as fibroblasts [1], [2]. Fibroblasts play a crucial role in tissue repair, from the late inflammatory phase until the fully final epithelization of the injured tissue, by secreting growth factors, cytokines, collagens and others extracellular matrix (ECM) components [3]-[6]. At the same time, fibroblast migration and proliferation bear crucial roles in the healing process, by initiating the proliferative phase of repair [7], [8].

Bioactive molecules found in different plant species from all over the world are now emerging as novel tools for therapeutic applications. Several studies revealed that plants produce potent antioxidants to control the oxidative stress caused by sunlight and oxygen, thus representing a source of 
new compounds with antioxidant activity [9]. Asteraceae (Compositae), is the family with the larger number of species among the Dicotyledons. Calendula arvensis L. and Helichrysum italicum (Roth) Don subsp. microphyllum (Willd.) Nym. belongs to this family [10][12] and are known to contain saponins, triterpenic alcohols and their fatty acid esters, carotenoids, flavonoids, coumarins, essential oils, hydrocarbons and fatty acids [13]. Traditional and folk medicinal uses include treatment of skin problems, fevers, chronic infections, wounds, bites and stings [14], [15]. Lavandula stoechas $\mathrm{L}$. is an important member of Labiatae (Lamiaceae) family. It is commonly used for various diseases of central nervous system (epilepsy and migraine), wound healing, decrease of blood sugar levels [16], and as antispasmodic, antiseptic, antimicrobial, sedative, diuretic and analgesic agent [17]-[19]. Nevertheless, it is also described that Lavender has a positive effects on urinary infections, cardiac diseases and eczema [20].

Plants are rich source of phytochemicals, which can have antioxidant properties and can promote wound healing. Reactive oxygen species (ROS) at high concentration counteract wound healing processes, due to cellular membranes damages. Moreover, high levels of ROS can induce severe tissue injuries even leading to neoplastic transformation [21]-[23]. Despite these toxic effects, ROS mediated signaling, representing a first response to different kind of cellular stressors, is also involved in tissue regeneration and fibroblast activation [24].

The biological potential of waste materials has been previously studied, in the attempt to employ post-distillation waste material of aromatic plants, thus creating both economic and ecologic benefits [25]-[27]. Actually, after volatile oils removal, waste plant materials are still abundant in phenolic compounds, oligomers and flavonoid glycosides with various biological activities [28], therefore these compounds could still have an application [29], [30]. Nevertheless, herb-herb combination have been used for thousand years, but scientific evidence of therapeutic benefits and a potential synergic effect of different compounds is not well defined yet [31].

In the present study we aimed at investigating fibroblast proliferation and wound-healing capabilities in vitro in the presence of waste extracts, after distillation of essential oils from different medicinal plants, endemic of the Mediterranean area. In particular, Calendula arvensis L., Lavandula stoechas L., Helichrysum italicum (Roth) Don subsp. microphyllum (Willd.) Nym. waste extracts, were tested, alone or in combination, in order to evaluate their synergic effects, for a potential antioxidant and wound healing activity.

\section{Materials and Methods}

\section{Materials}

Dulbecco's modified Eagle's medium (DMEM), fetal bovine serum (FBS), L-glutamine and trypsin/ EDTA were all purchased from Invitrogen, Carlsbad, CA. $200 \mathrm{U} / \mathrm{mL}$ penicillin $-0.1 \mathrm{mg} / \mathrm{mL}$ streptomycin and Dulbecco's phosphate buffered saline (DPBS) were from Euroclone, Milano, Italy. Chemicals used were purchased from Sigma-Aldrich Italy (IT), and were of the highest analytical grade. Standards of chlorogenic acid, quercetin, luteolin, rosmarinic acid, apigenin, and naringenin were purchased from Extrasinthese (Lyon, France). Acetonitrile (Sigma, Milano - Italy) was of HPLC grade. Orthophosphoric acid (ACS ISO, for analysis, 85\%) were purchased from Carlo Erba. Water was distilled and filtered through a Milli-Qapparatus (Millipore, Milan, Italy) before use.

\section{Sample collection}

Plant materials, C. arvensis, L. stoechas, H. italicum, were collected during spring 2017 in the Asinara National Park, exactly on Cala Reale bay. The leaves were dried at room temperature for 5 days and then were cut in fragments of approximately $5 \mathrm{~cm}$. Thereafter 175 gr of each fraction was placed in a round-bottom flask with $1000 \mathrm{ml}$ of distilled and deionized water at final concentration of $17.5 \%$. The flask was coupled to a Clevenger-type system to perform steam distillation. In this condition plant materials remained in contact with boiling water for 4 $h$ in order to extract the essential oil of $C$. arvensis (C), L. stoechas $(\mathrm{L}), H$. italicum $(\mathrm{H})$. In order to determine the concentration of each extract, $1 \mathrm{~mL}$ of waste extract was lyophilized on a Eppendorf Concentrator plus, obtaining a concentration of $41.93 \mu \mathrm{g} / \mu \mathrm{L}$ for Calendula arvensis L., $26.17 \mu \mathrm{g} / \mu \mathrm{L}$ for Helichrysum italicum (Roth) Don subsp. microphyllum (Willd.) Nym. and $39.93 \mu \mathrm{g} / \mu \mathrm{L}$ for Lavandula stoechas $L$. The residual water decoction (waste extracts), which was typically discarded, were centrifuged, filtrated and used for the assays. In addition, to evaluate the synergic effect, 500 $\mathrm{ml}$ of each waste extract were combined as follow:

1) C. arvensis, L. stoechas, $H$. italicum (CLH)

2) C. arvensis, L. stoechas (CL)

3) C. arvensis, $\mathrm{H}$. italicum $(\mathrm{CH})$

4) L. stoechas, H. italicum (LH)

The final concentration of combined extracts was $38.90 \mu \mathrm{g} / \mu \mathrm{L}$ for $\mathrm{CLH}, 45.32 \mu \mathrm{g} / \mu \mathrm{L}$ for $\mathrm{CL}, 33.25$ $\mu \mathrm{g} / \mu \mathrm{L}$ for $\mathrm{CH}$ and $38.13 \mu \mathrm{g} / \mu \mathrm{L}$ for $\mathrm{LH}$.

\section{Determination of total phenols}

Total phenols were quantified by a colorimetric assay based on procedures described by Lizcano et al 
(2010), as previously described [32]. Basically,100 $\mu 1$ of different concentrations of samples (from 0.1, to 1000 $\mu \mathrm{g} / \mathrm{mL}$ ) were added to $900 \mu \mathrm{l}$ of bi-distillated water and $75 \mu \mathrm{l}$ of Folin-Ciocalteau phenol reagent. After 2 min, $200 \mu \mathrm{l}$ of sodium bicarbonate $(75 \mathrm{~g} / \mathrm{l})$ were added to the mixture and incubated in the dark for 60 $\mathrm{min}$ at room temperature. The absorbance was readed at $770 \mathrm{~nm}$ using a $1 \mathrm{~cm}$ quartz cuvette on an Ultrospec 4300 pro UV-vis spectrophotometer, equipped with a temperature controller set to $25^{\circ} \mathrm{C}$. Gallic acid (1-200 $\mu \mathrm{g})$ was used as standard. Results were expressed as $\mu \mathrm{g}$ of gallic acid equivalent (GAE) per mg of the dried plant part.

\section{Stock standard solutions of polyphenols}

Stock standard solutions of $1000 \mathrm{mg} / \mathrm{l}$ for individual standards was prepared in methanol by dissolving an exactly known mass of solute in a specific volume of solvent. These starting solutions were used to prepare one standard mixture. A serial dilutions of this intermediary standard solution, were made by diluting more concentrated solution with $0.22 \mathrm{M}$ phosphoric acid to obtain mixed reference solutions in the range of $0.1-20 \mathrm{mg} / \mathrm{l}$. These solutions were used for external standard calibration, linearity check and determination of limits of detection (LOD) and limits of quantitation (LOQ). All standard solutions were stored in the dark at $-20^{\circ} \mathrm{C}$ until usage.

\section{HPLC analysis}

The HPLC experiments were performed according to a method previously reported by Sarais et al. and appropriately modified [33]. Briefly, the analysis was performed on an Agilent 1100 series HPLC system (Agilent Technologies, Milan, Italy) equipped with a quaternary pump, a vacuum degasser, an autosampler and a thermostated column compartment and coupled with a diode array detector (DAD) UV6000LP (Thermo Finnigan, Milan, Italy) using a data acquisition software ChromQuest version 4.0. A reversed-phase column Kinetex C18, 100 A $(150 \times 4.6 \mathrm{~mm}, 5 \mathrm{u})$ from Phenomenex, maintained at $22^{\circ} \mathrm{C}$, was used. The chromatographic separation was obtained by gradient elution with an aqueous solution containing $0.22 \mathrm{M}$ phosphoric acid (solvent A) and acetonitrile (solvent B) at a constant flow rate of $0.4 \mathrm{ml} / \mathrm{min}$. An increasing linear gradient of solvent $\mathrm{B}$ was used starting from $5 \%$ and reaching $80 \%$ in 120 minutes. The column was equilibrated for $15 \mathrm{~min}$ before the next sample injections. The injection volume was $10 \mu \mathrm{l}$. A multi-wavelength endpoint detection was chosen for qualitative and quantitative analysis. Typical wavelength is $280 \mathrm{~nm}$ and $360 \mathrm{~nm}$ for measurement of chlorogenic acid, quercetin, luteolin, rosmarinic acid, apigenin, and naringenin respectively. The contents of the active ingredients were expressed as milligrams of active ingredient per $\mathrm{L}$ of extract. All analyses were replicated three times. Data were expressed as the mean \pm standard deviation (SD).

\section{Antioxidant Assay}

The ABTS (2,2-azinobis (3-ethylbenzothiazoline6-sulfonic acid)) free radical-scavenging activity of each sample was determined according to the method described by Petretto et al (2015) [34]. It involves the direct production of the blue/green ABTS + chromophore through the reaction between ABTS and potassium persulfate, as previously described [32]. ABTS was dissolved in water to give a final concentration of $7 \mathrm{mM}$. ABTS.+ was produced by the reaction of ABTS stock solution with $2.45 \mathrm{mM}$ potassium persulfate (final concentration) and allowing the mixture to stand in the dark at room temperature for 12-16 $\mathrm{h}$ before use. The ABTS.+ solution was diluted with bi-distillated water to an absorbance of $0.7( \pm 0.02)$ at $734 \mathrm{~nm}$. In order to measure the antioxidant activity of waste extracts and their synergic effects, $100 \mu \mathrm{l}$ of aqueous extracts solution at various concentrations (from 0.1 to 100 $\mu \mathrm{g} / \mathrm{mL}$ ) were added to $900 \mu \mathrm{L}$ of diluted ABTS.+ and the absorbance recorded at time zero and after $50 \mathrm{~min}$ at which point the absorbance was stable. Each concentration was analyzed in triplicate. The discoloration percentage at $734 \mathrm{~nm}$ was calculated for each point; the antioxidant capacity of the test compound was expressed in percent inhibition (\%), and the $\mathrm{IC}_{50}$ value, the amount of an extract that neutralize $50 \%$ of the radical, was calculated from regression analysis and expressed as mean $\pm \mathrm{SD}$.

\section{Cell Culture}

The human foreskin fibroblasts 1 (HFF1), purchased from American Type Culture Collection (ATCC), were routinely cultured in DMEM low glucose supplemented with $2 \mathrm{mM}$ L-glutamine and $10 \%(\mathrm{v} / \mathrm{v})$ FBS. All cells were grown in $1 \%$ antibiotic/antimitotic media at $37{ }^{\circ} \mathrm{C}$ and $5 \%(\mathrm{v} / \mathrm{v})$ $\mathrm{CO}_{2}$. Cells for the experiments were used at passage 5 .

\section{MTT Viability assay}

To evaluate cytotoxicity of different plants extracts, fibroblasts were seeded at a concentration of 7,000 cells/well and allowed to incubate overnight. Once attached at wells surface, cells were washed in phosphate buffered saline (PBS). Than cells were cultured with a medium conditioned with different concentrations $(1,5,10 \mu \mathrm{L} / \mathrm{mL})$ of each waste extracts of $\mathrm{C}$, or $\mathrm{L}$ or $\mathrm{H}$, or with the combination of 2 or 3 plants waste extracts (CLH, CL, CH, LH), for $24 \mathrm{~h}, 48 \mathrm{~h}$, $72 \mathrm{~h}, 96 \mathrm{~h}$ or 120 hours. At the indicated time points, 
the culturing medium was discarded, and MTT reagent was added at the final concentration of 650 $\mu \mathrm{g} / \mathrm{mL}$. After $2 \mathrm{~h}$ of incubation with $650 \mu \mathrm{g} / \mathrm{mL}$ MTT reagent, formazan was dissolved in DMSO and absorbance detected at $570 \mathrm{~nm}$ using Varian50 MPR, Microplate reader. The results expressed in OD units as compared to untreated cells. Data are expressed as mean \pm SD referring to the control.The viability of treated cells vs control was calculated as follow:

$\%$ cell viability $=($ OD570 treated cells $) \times 100 /($ OD570 control).

\section{Proliferation and migration assay}

Fibroblasts were seeded at a concentration of 35,000 cells/well and allowed to incubate until confluence. A scratch was made in each well using a $200 \mu l$ pipette tip. Media was removed and cells were washed in PBS before adding the medium conditioned with different concentrations $(1,5$, or 10 $\mu \mathrm{L} / \mathrm{mL}$ ) of each waste extracts of $\mathrm{C}$, or $\mathrm{L}$, or $\mathrm{H}$, or with the combination of 2 or 3 plants waste extracts $(\mathrm{CLH}$, $\mathrm{CL}, \mathrm{CH}, \mathrm{LH}$ ).

Five different areas along the scratches of each wells were analyzed by optical microscopy after 0,24 , 48,72 , and 96 hours following the induced damage. The distance between each edges of the scratch was measured using the software ImageJ and expressed as percentage of closure of the area as compared to control untreated cells.

\section{Immunostaining}

Fibroblasts were seeded at a concentration of 20,000 cells/well and a scratch was made in each well using a $200 \mu$ pipette tip before adding the medium conditioned with different concentrations $(1,5$, or 10 $\mu \mathrm{L} / \mathrm{mL}$ ) of each waste extracts of $\mathrm{C}$, or $\mathrm{L}$, or $\mathrm{H}$, or with the combination of 2 or 3 plants waste extracts $(\mathrm{CLH}$, $\mathrm{CL}, \mathrm{CH}, \mathrm{LH}$ ). Control cells were maintained in the presence of a basic growing medium. At the end of wound closure (72 hours), cells were fixed with $4 \%$ of pharaformaldeide (Sigma Aldrich Chemie $\mathrm{GmbH}$, Germany) for $30 \mathrm{~min}$. After permeabilization by $0.1 \%$ Triton X-100 (Life Technologies, USA)-PBS, cells were washed in PBS three times for $5 \mathrm{~min}$ and incubated with 3\% Bovine Serum Albumine (BSA) $-0.1 \%$ Triton $\mathrm{X}-100$ in PBS (Life Technologies, USA) for $30 \mathrm{~min}$ and then exposed overnight at $4{ }^{\circ} \mathrm{C}$ to the primary anti-rabbit anti-Collagen I antibody (Abcam, United Kingdom) and anti-Collagen III antibody (Abcam, United Kingdom). Finally, cells were washed in PBS two times for $5 \mathrm{~min}$ and stained at $37^{\circ} \mathrm{C}$ for $1 \mathrm{~h}$ in the dark with the fluorescence-conjugated goat anti rabbit IgG secondary antibody (Life Technologies, USA). Nuclei were labelled with $1 \mu \mathrm{g} / \mathrm{mL}$ 4,6-diamidino-2phenylindole (DAPI). All microscopy analyses were performed with a confocal microscope (TCS SP5, Leica, Nussloch, Germany).

\section{Statistical analyses}

The experiments were performed two times with three technical replicates for each treatment. All statistical analyses were performed by comparing waste extracts from leaves from $\mathrm{C}$, or $\mathrm{L}$ or $\mathrm{H}$ using unpaired Student's t-test, and, using SigmaStat v 3.5 software when the data followed a normal distribution. The distribution of the sample was evaluated by the Kolmogorov-Smirnov and Shapiro tests. Differences in total phenols amounts between waste extracts of $\mathrm{C}$, or $\mathrm{L}$ or $\mathrm{H}$ were assessed using linear regression in which the slope and intercept variations were compared with a global test of coincidence using GraphPad Prism 6 software. The association between variables was analyzed by the Pearson product moment correlation coefficient when the data were normally distributed. A $\mathrm{P} \leq 0.05$ was considered statistically significant.

\section{Results}

\section{Phenols are present in all waste extracts}

A preliminary screening of polyphenol total content was performed using the Folin-Ciocalteau method. As reported in Table 1, total phenolic amounts, expressed as GAE were higher in extracts from $\mathrm{L}$ and $\mathrm{H}$ as compared to $\mathrm{C}$. If we considered the differences between linear regression, the comparison of slopes, in C (14.60 \pm 0.06$)$ (light blue line), in $\mathrm{H}$ $(24.74 \pm 3.11)$ (pink line) and in L (26.55 \pm 8.49$)$ (purple line) were not significantly different. However, the comparison of intercepts between C (18.86 \pm 0.76$), \mathrm{H}$ $(68.98 \pm 42.60)$ and L $(217.4 \pm 116.30)$ was significantly different with a $\mathrm{P}<0.01$ (Figure 1, panel a).

Table 3 shows that the pool of CLH, CL and LH exhibited a higher phenolic amount as compared to $\mathrm{CH}$. As reported in figure 1 (panel b), the comparison of slopes, in CLH (24.74 \pm 5.22$)$ (light blue line), in CL $(24.63 \pm 4.91)$ (pink line), $\mathrm{CH}(19.32 \pm 1.07)$ (purple line), and in LH (21.60 \pm 6.46$)$ (grey line) were not significantly different. However, the comparison of intercepts between CLH (116.2 \pm 71.50), CL (124.2 \pm 67.31), $\mathrm{CH}(45.81 \pm 14.72)$ and in LH (200.4 \pm 88.54) was significantly different with a $\mathrm{P}<0.05$ (Figure 1 panel b).

Quantitative results are reported in Table 2 and Table 4. Results are expressed as mean \pm standard deviation of 3 determinations. To facilitate the qualitative methodology approach, samples were subjected to the analysis with a screening process by selecting multiple wavelengths in a diode array detector. Particularly, wavelengths of 280, and 360 were chosen to analyze phenolic fraction of samples. All phenols, 
identified according to their retention time and their UV spectrum, were quantified by external standard method. All waste extracts showed high quantity of water-soluble phenols belonging to different chemical classes. Due to the complexity of matrices, quantitative analysis was carried out by collecting phytochemicals in different groups according to their UV spectrum. As we can see (Table 3) caffeoylquinic acid derivatives were the most abundant compounds present in $\mathrm{C}$ and $\mathrm{H}(112.21 \pm 6.22 \mathrm{mg} / \mathrm{L}$ and $379.76 \pm$ $11.25 \mathrm{mg} / \mathrm{L}$ respectively). Rosmarinic acid and rosmarinic acid derivatives were higher in L (382.46 \pm $15.02 \mathrm{mg} / \mathrm{L}, 249.80 \pm 8.15 \mathrm{mg} / \mathrm{L}$ respectively) followed by caffeoylquinic acid derivatives $(77.77 \pm 5.20 \mathrm{mg} / \mathrm{L})$. Table 4 (DA FARE) shows quantitative results of pool of $\mathrm{CLH}, \mathrm{CL}, \mathrm{CH}$ and LH. Caffeoylquinic acid derivatives were the most abundant compounds present in CLH $(54.84 \pm 2.29 \mathrm{mg} / \mathrm{L}), \mathrm{CH}(262.18 \pm$ $9.51 \mathrm{mg} / \mathrm{L})$ and LH $(207.85 \pm 7.51 \mathrm{mg} / \mathrm{L})$ while rosmarinic acid was higher in CL (160.02 $\pm 8.98 \mathrm{mg} / \mathrm{L})$.

\section{Plant waste extracts exhibit antioxidant properties related to the phenolic concentration}

As shown in Figure 2 (panel a), antioxidant activity of $\mathrm{L}$ extract (purple bars) was significantly higher $(\mathrm{P}<0.01)$ as compared to $\mathrm{C}$ extract (light blue bars), along with the ABTS assay-time course. Also, $\mathrm{H}$ (pink bars) showed a high antioxidant activity similar to $\mathrm{L}$ after $50 \mathrm{~min}$ of incubation, but slightly lower if compared to $\mathrm{C}$, at time zero. This data is related to the minor concentration of total phenolic amounts in C (Table 1). We also show (Table 5) a positive Spearman correlation between antioxidant activity measured by ABTS and total phenolic contents $(\mathrm{P}<0.05)$. Pooled waste extracts (CLH, CL, CH, LH) exhibited a sensible antioxidant activity, nearly superimposable to the antioxidant Trolox (green bars), used as positive control. The higher antioxidant activity was obtained with LH (IC50 of $8.54 \pm 0.82 \mu \mathrm{g} / \mathrm{mL}$ ), showing an effect similar to Trolox. If we consider the difference

between groups of pooled waste extracts, antioxidant activity was significantly higher, after $50 \mathrm{~min}$, in LH (grey bars) as compared to CL (pink bars) (figure 2 panel b).

Table 1. Determination of phenols by Folin-Ciocalteau's method.

\begin{tabular}{llll}
\hline & C & H & L \\
$(\mu \mathrm{L})$ & $\mu \mathrm{g} \mathrm{GAE}$ & $\mu \mathrm{g} \mathrm{GAE}$ & $\mu \mathrm{g} \mathrm{GAE}$ \\
\hline 25.00 & $384.08 \pm 37.58$ & $663.11 \pm 42.71^{*}$ & $819.62 \pm 57.20^{*}$ \\
10.00 & $164.56 \pm 6.61$ & $378.05 \pm 37.34$ & $612.85 \pm 48.88$ \\
5.00 & $90.89 \pm 7.15$ & $199.36 \pm 20.78$ & $426.90 \pm 140.77$ \\
1.00 & $34.43 \pm 4.63$ & $49.55 \pm 7.40$ & $98.70 \pm 21.38$ \\
\hline
\end{tabular}

Data were expressed as mean \pm SD of 3 independent experiments and indicated as $\mu \mathrm{g}$ of gallic acid equivalent (GAE). A * $\mathrm{P}<0.05$ was considered significant. $C$. arvensis $=(\mathrm{C})$, H. italicum $=(\mathrm{H})$, L. stoechas $=(\mathrm{L})$.

Table 2. Phenolic compounds quantified in $C, L$ and $H$ decoction water.

\begin{tabular}{|c|c|c|c|}
\hline Phenolic compounds & $\begin{array}{l}\mathrm{C} \\
\mathrm{mg} / \mathrm{L} \pm \mathrm{DS}\end{array}$ & $\begin{array}{l}\mathrm{H} \\
\mathrm{mg} / \mathrm{L} \pm \mathrm{DS}\end{array}$ & $\begin{array}{l}\mathrm{L} \\
\mathrm{mg} / \mathrm{L} \pm \mathrm{DS}\end{array}$ \\
\hline $\begin{array}{l}\text { Caffeoylquinic acid } \\
\text { derivatives }^{( \pm)}\end{array}$ & $112.21 \pm 6.22$ & $379.76 \pm 11.25$ & $77.77 \pm 5.20$ \\
\hline $\begin{array}{l}\text { Quercetin glycoside } \\
\text { derivatives }(\&)\end{array}$ & $70.84 \pm 5.14$ & - & - \\
\hline Luteolina derivatives(s) & - & - & $54.49 \pm 5.02$ \\
\hline Rosmarinic acid & - & - & $382.46 \pm 15.02$ \\
\hline Rosmarinic acid derivatives $(\$)$ & - & - & $249.80 \pm 8.15$ \\
\hline Apigenin derivatives(§) & - & - & $18.40 \pm 1.55$ \\
\hline Naringenin derivatives ${ }^{(๗)}$ & - & $24.02 \pm 0.87$ & - \\
\hline
\end{tabular}

Results are expressed as mean \pm standard deviation of 3 determinations. (£) Caffeoylquinic acid derivatives were expressed as chlorogenic acid. (\&) Quercetin glycoside derivatives were expressed as quercetin. (ç) Luteolin glycoside derivatives were expressed as luteolin. (\$) Rosmarinic acid derivatives were expressed as rosmarinic acid. (§) Apigenin glycoside derivatives were expressed as apigenin. (ø) Naringenin glycoside derivatives were expressed as naringenin.

Table 3. Determination of phenols by Folin-Ciocalteau's method of pooled waste extracts.

\begin{tabular}{|c|c|c|c|c|}
\hline$(\mu \mathrm{L})$ & $\begin{array}{l}\text { CLH } \\
\mu \mathrm{g} \mathrm{GAE}\end{array}$ & $\begin{array}{l}\text { CL } \\
\mu \mathrm{g} \text { GAE }\end{array}$ & $\begin{array}{l}\mathrm{CH} \\
\mu \mathrm{g} \text { GAE }\end{array}$ & $\begin{array}{l}\text { LH } \\
\mu \mathrm{g} \text { GAE }\end{array}$ \\
\hline 25.00 & $693.88 \pm 5.01^{*}$ & $701.77 \pm 19.22^{*}$ & $524.48 \pm 65.77$ & $697.73 \pm 27.33^{*}$ \\
\hline 10.00 & $471.66 \pm 189.91$ & $465.15 \pm 133.34$ & $241.20 \pm 106.28$ & $495.22 \pm 87.77$ \\
\hline 5.00 & $240.77 \pm 74.10$ & $265.30 \pm 79.93$ & $162.58 \pm 54.77$ & $387.77 \pm 213.59$ \\
\hline 1.00 & $72.61 \pm 36.75$ & $75.26 \pm 31.80$ & $46.89 \pm 6.48$ & $106.72 \pm 25.10$ \\
\hline
\end{tabular}

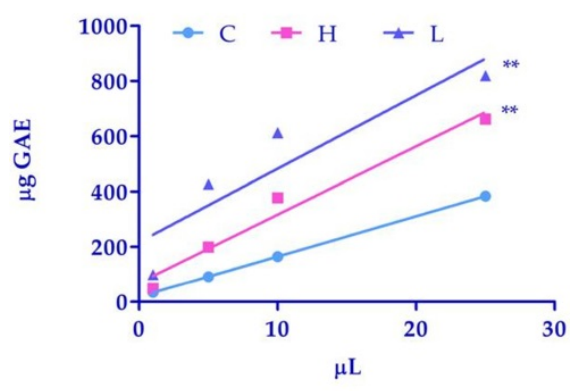

(a)

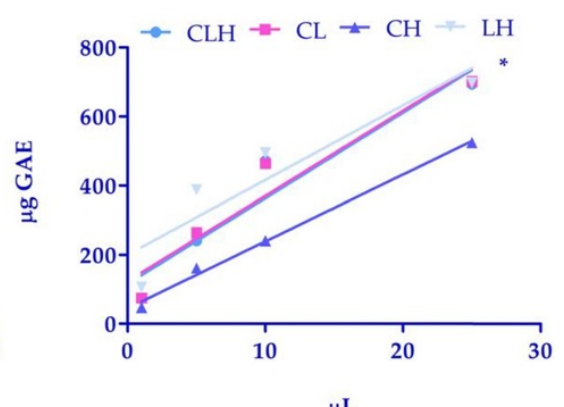

(b)

Figure 1. (a) Linear regression analysis of phenols amounts of waste extracts of $C$. arvensis (C), L. stoechas (L), and H. italicum $(H)$ and $(\mathbf{b})$ pooled waste extracts of $C$. arvensis, $L$. stoechas, and $H$. italicum $(C L H, C L, C H, L H)$ over volumes. Data were expressed as mean of 3 independent experiments $(* P<0.05 ; * * P<0.01)$. 


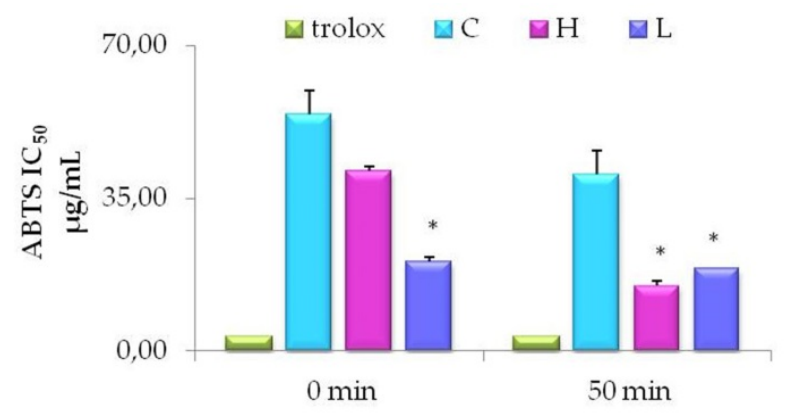

(a)

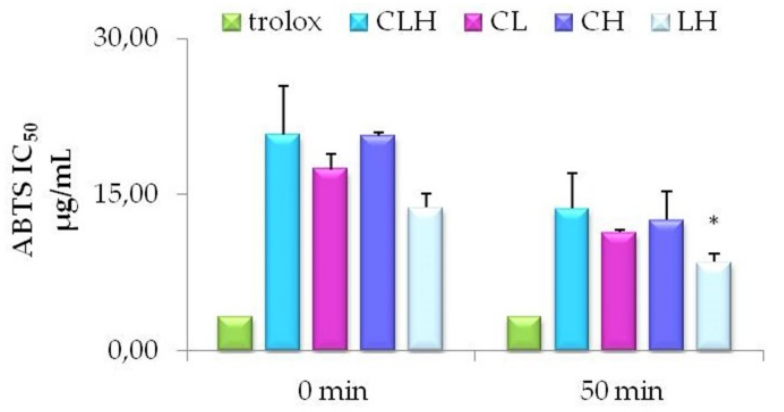

(b)

Figure 2. Time-course of antioxidant activity of waste extracts from leaves of $C$. arvensis $(\mathrm{C}), \mathrm{L}$. stoechas $(\mathrm{L})$, and $H$. italicum $(\mathrm{H})$ and pooled waste extracts $(\mathrm{CLH}, \mathrm{CL}, \mathrm{CH}, \mathrm{LH})$ evaluated by ABTS assays. (a) Free radical scavenging of $50 \%$ of ABTS by Trolox, used as standard, $\mathrm{C}$ or $\mathrm{L}$ or $\mathrm{H}$ at the indicated time-points. The values are expressed as mean \pm SD of three independent assays ( $* \mathrm{P}<0.05$ ). (b) Free radical scavenging of $50 \%$ of ABTS by Trolox, and pooled waste extracts $\mathrm{CLH}, \mathrm{CL}$, $\mathrm{CH}$, $\mathrm{LH}$ at the indicated time points. The values are expressed as mean $\pm \mathrm{SD}$ of three independent assays $(* \mathrm{P}<0.05)$.

Table 4. Phenolic compounds quantified in $\mathrm{CLH}, \mathrm{CL}, \mathrm{CH}$ and $\mathrm{LH}$ decoction water.

\begin{tabular}{|c|c|c|c|c|}
\hline Phenolic compounds & $\begin{array}{l}\text { CLH mg/L } \pm \\
\text { DS }\end{array}$ & $\begin{array}{l}\text { CL mg/L } \pm \\
\text { DS }\end{array}$ & $\begin{array}{l}\mathrm{CH} \mathrm{mg} / \mathrm{L} \pm \\
\mathrm{DS}\end{array}$ & $\begin{array}{l}\text { LH mg/L } \pm \\
\text { DS }\end{array}$ \\
\hline $\begin{array}{l}\text { Caffeoylquinic acid } \\
\text { derivatives }^{(£)}\end{array}$ & $54.84 \pm 2.29$ & $65.62 \pm 3.22$ & $262.18 \pm 9.51$ & $207.85 \pm 7.51$ \\
\hline Luteolin derivatives $(\&)$ & $21.84 \pm 0.87$ & $45.45 \pm 1.76$ & - & $35.60 \pm 2.00$ \\
\hline Rosmarinic acid & $29.20 \pm 1.59$ & $160.02 \pm 8.98$ & - & $81.95 \pm 4.02$ \\
\hline $\begin{array}{l}\text { Rosmarinic acid } \\
\text { derivatives }(\$)\end{array}$ & - & $79.86 \pm 4.15$ & - & $29.12 \pm 1.49$ \\
\hline $\begin{array}{l}\text { Quercetin glycoside } \\
\text { derivatives(s) }\end{array}$ & $28.68 \pm 0.98$ & $40.30 \pm 1.05$ & $28.98 \pm 1.09$ & - \\
\hline $\begin{array}{l}\text { Apigenin } \\
\text { derivatives(\$) }\end{array}$ & $17.98 \pm 1.02$ & - & - & $5.68 \pm 0.08$ \\
\hline $\begin{array}{l}\text { Neoeriocitrin } \\
\text { derivative }^{(ø)}\end{array}$ & $41.92 \pm 1.54$ & - & $26.49 \pm 1.05$ & $14.93 \pm 0.29$ \\
\hline \multicolumn{5}{|c|}{$\begin{array}{l}\text { Results are expressed as mean } \pm \text { standard deviation of } 3 \text { determinations. } \\
\text { (£) Caffeoylquinic acid derivatives were expressed as chlorogenic acid. (\&) Luteolin } \\
\text { glycoside derivatives were expressed as luteolin. (\$) Rosmarinic acid derivatives } \\
\text { were expressed as rosmarinic acid. (ç)Quercetin glycoside derivatives were } \\
\text { expressed as quercetin. (§) Apigenin glycoside derivatives were expressed as } \\
\text { apigenin. (ø)Neoeriocitrin glycoside derivatives were expressed as neoeriocitrin. }\end{array}$} \\
\hline
\end{tabular}

Table 5. Spearman correlation between absolute value of antioxidant activity and phenols amounts

\begin{tabular}{|c|c|c|c|c|c|c|c|}
\hline$(\mu \mathrm{L})$ & $\begin{array}{l}\text { ABTS } \\
\text { C }\end{array}$ & $\begin{array}{l}\text { Phenols } \\
\text { C }\end{array}$ & $\begin{array}{l}\text { ABTS } \\
\text { L }\end{array}$ & $\begin{array}{l}\text { Phenols } \\
\text { L }\end{array}$ & $\begin{array}{l}\text { ABTS } \\
\text { H }\end{array}$ & $\begin{array}{l}\text { Phenols } \\
\text { H }\end{array}$ & $\begin{array}{l}\text { Spearman } \\
\text { correlation }\end{array}$ \\
\hline 25,00 & 107,25 & 384,08 & 112,34 & 819,62 & 108,12 & 663,11 & $\mathrm{P}<0.05$ \\
\hline 10,00 & 103,87 & 164,56 & 110,13 & 612,85 & 107,93 & 378,05 & \\
\hline 5,00 & 93,88 & 90,89 & 108,34 & 426,90 & 105,24 & 199,36 & \\
\hline 1,00 & 52,43 & 34,43 & 105,98 & 98,70 & 87,11 & 49,55 & \\
\hline
\end{tabular}

\section{Waste extracts stimulated cell viability}

MTT assay revealed that $10 \mu \mathrm{L} / \mathrm{mL} \mathrm{L}$ extract (purple bars) significantly decreased cell viability, while stimulating cell viability at lower concentrations (5, or $1 \mu \mathrm{L} / \mathrm{mL}$ ) (Figure 3, panel a). Nevertheless, only after 96 hours of culturing with 5 $\mu \mathrm{L} / \mathrm{mL} \quad \mathrm{L}$ waste extract the stimulation was statistically different $(\mathrm{P}<0.05)$ as compared to control untreated cells (Figure 3, panel d). No cytotoxic effects were detected when cells were cultured with different concentrations (from 1 to $10 \mu \mathrm{L} / \mathrm{mL}$ ) of $\mathrm{C}$ waste extract (light blue bars). However, in cells cultured with $C$ waste extract cell viability was significantly induced after 96-120 hours of culturing, as compared to control untreated cells, being more effective at a lower concentration $(1 \mu \mathrm{L} / \mathrm{mL})$ (Figure 3, panel d-e). A similar effect on cell viability could be detected when cells were cultured for 96 hours in the presence of $1-10 \mu \mathrm{L} / \mathrm{mL} \mathrm{H}$ (pink bars) $(\mathrm{P}<0.01$ and $\mathrm{P}<0.05$ respectively) waste extract (Figure 3, panel d).

In the presence of all the pooled waste extracts, CLH (light blue bars), CL (pink bars), $\mathrm{CH}$ (purple bars), LH (grey bars) (Figure 4), cell viability was similar to control untreated cells until $72 \mathrm{~h}$ of treatment, while decreasing for longer periods (96, or 120 hours) (Figure 4, panel d-e) for all the concentration tested. In particular, CLH pooled waste extracts (light blue bars), were able to induce fibroblast viability with a trend comparable to control untreated cells (dark blue bars) (Figure 4, panel a-e). Nevertheless, only after $72 \mathrm{~h}$ of culturing with 1 $\mu \mathrm{L} / \mathrm{mL} \mathrm{CLH}$, cell viability was significantly higher $(\mathrm{P}<0.05)$ as compared to control untreated cells (Figure 4, panel c).

\section{Waste extracts were able to induce wound repair}

The ability of waste extracts from leaves of C or L or $\mathrm{H}$ to stimulate fibroblast proliferation and/or migration was visualized by the scratch assay. Figure 5 shows the migration of fibroblasts after scratch and culture with $1 \mu \mathrm{L} / \mathrm{mL}$ L extract, being an example of the single extract effect on wound healing $(C, L, H)$. L waste extract increased the number of cells detectable in the artificial wound site (Table 6) reaching the maximum stimulatory effect, after $72 \mathrm{~h}$ of treatment (Table 6). When cells were cultured with $1 \mu \mathrm{L} / \mathrm{mL}$ of $\mathrm{C}$ or $\mathrm{H}$ waste extracts a lower migration and proliferation activity was observed, as compared to L-treated cells (Table 6). 


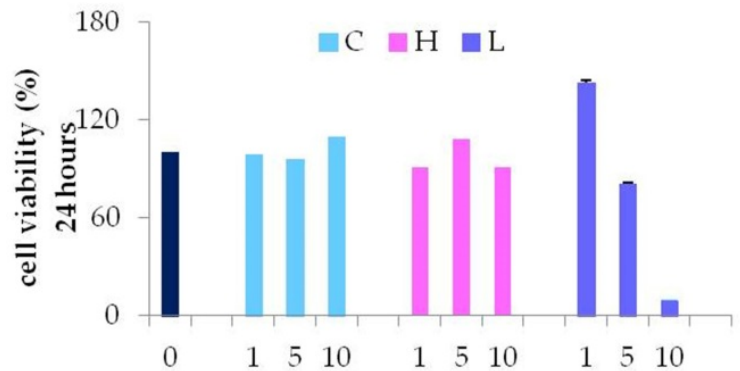

(a)
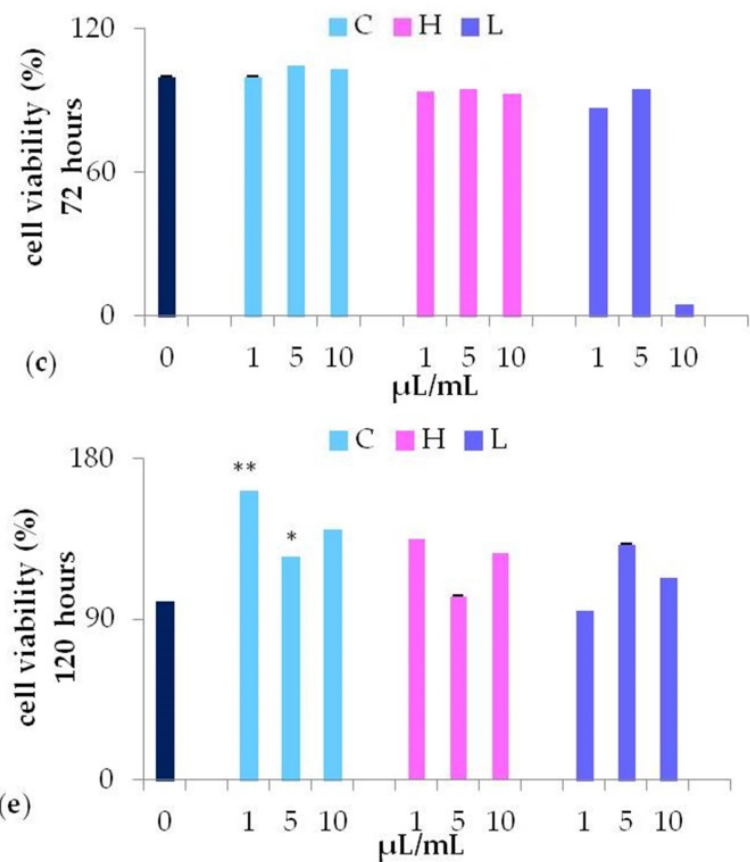
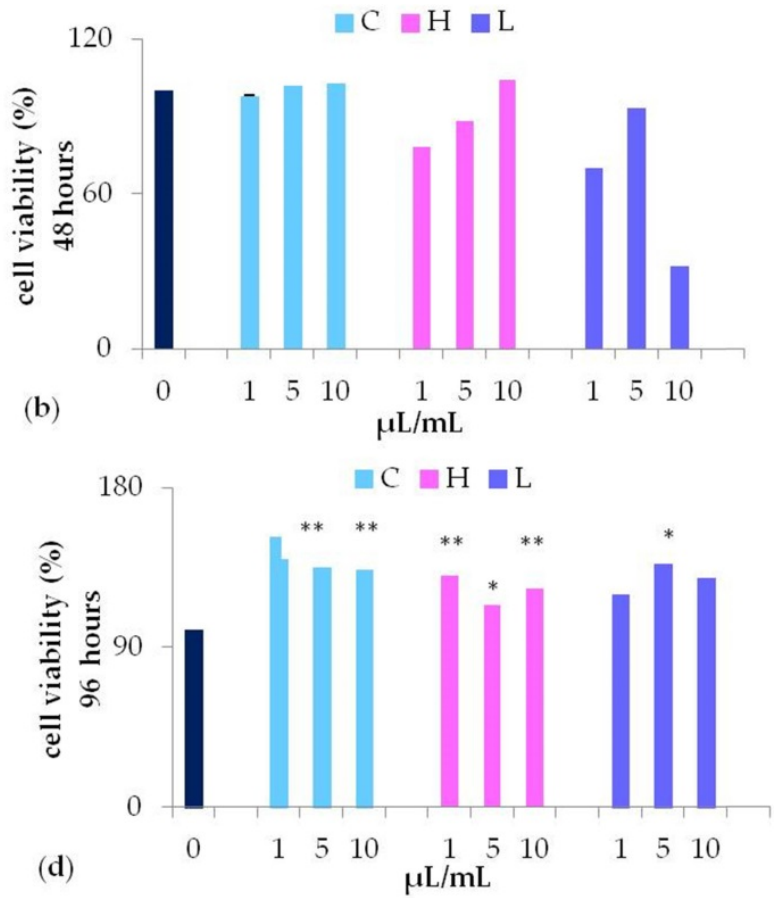

Figure 3. MTT assay of waste extract of $C$. arvensis $(C)$, L. stoechas $(\mathrm{L})$, and $H$. italicum $(\mathrm{H})$ at different concentration $(1,5,10 \mu \mathrm{L} / \mathrm{mL})$ after $24 \mathrm{~h}(\mathbf{a}), 48 \mathrm{~h}(\mathrm{~b}), 72 \mathrm{~h}(\mathbf{c}), 96 \mathrm{~h}(\mathrm{~d})$ and $120 \mathrm{~h}(\mathrm{e}) \mathrm{N}^{*} \mathrm{p}<0.05 * * \mathrm{p}<0.01$ as compared to untreated control $(0)$.

Table 6. Migration and proliferation of fibroblasts stimulated by waste extracts

\begin{tabular}{|c|c|c|c|c|c|c|c|c|c|c|}
\hline \multirow[t]{2}{*}{ hours } & \multirow[t]{2}{*}{ Untreated } & \multicolumn{3}{|l|}{$\mathrm{C}$} & \multicolumn{3}{|l|}{ L } & \multicolumn{3}{|l|}{$\mathbf{H}$} \\
\hline & & $1 \mu \mathrm{L} / \mathrm{mL}$ & $5 \mu \mathrm{L} / \mathrm{mL}$ & $10 \mu \mathrm{L} / \mathrm{mL}$ & $1 \mu \mathrm{L} / \mathrm{mL}$ & $5 \mu \mathrm{L} / \mathrm{mL}$ & $10 \mu \mathrm{L} / \mathrm{mL}$ & $1 \mu \mathrm{L} / \mathrm{mL}$ & $5 \mu \mathrm{L} / \mathrm{mL}$ & $10 \mu \mathrm{L} / \mathrm{mL}$ \\
\hline 24 & $16.2 \pm 2.5$ & $21.3 \pm 1.68$ & $20.3 \pm 2.9$ & $20.1 \pm 2.5$ & $21.7 \pm 3.0$ & $16.7 \pm 1.3$ & $14.1 \pm 3.2$ & $14.2 \pm 3.4$ & $17.1 \pm 3.0$ & $14.4 \pm 1.9$ \\
\hline 48 & $20.4 \pm 0.4$ & $26.1 \pm 0.8$ & $22.8 \pm 0.4$ & $23.1 \pm 0.6$ & $27.4 \pm 1.9$ & $21.7 \pm 1.7$ & $21.0 \pm 3.6$ & $19.3 \pm 0.2$ & $22.8 \pm 0.3$ & $16.0 \pm 0.0$ \\
\hline 72 & $21.0 \pm 0.0$ & $27.2 \pm 0.0$ & $23.8 \pm 0.0$ & $24.1 \pm 0.0$ & $29.2 \pm 0.5$ & $21.1 \pm 0.6$ & $23.85 \pm 0.6$ & $19.9 \pm 0.0$ & $23.6 \pm 0.0$ & $16.4 \pm 0.0$ \\
\hline
\end{tabular}

Data were expressed as wound closure percentage $(\%)$ at different time points $(24,48,72$ hours $)$ untreated and stimulated by C. arvensis $=(\mathrm{C})$, L. stoechas $=(\mathrm{L})$, and $H$. italicum $=(\mathrm{H})$, at different concentration $(1,5,10 \mu \mathrm{L} / \mathrm{mL})$.

The migration and proliferation of fibroblasts was stimulated as early as $24 \mathrm{~h}$ by waste extracts of $\mathrm{L}$ or $\mathrm{C}$ as compared to control untreated cells, with a wound closure of $21,3 \%$, and $21,7 \%$ respectively when a concentration of $1 \mu \mathrm{L} / \mathrm{mL}$ was applied.

Wound closure was also stimulated after 48 and 72 hours of culturing with low concentration (1 $\mu \mathrm{L} / \mathrm{mL})$ of both $\mathrm{L}(27.4 \%$ and $29.2 \%)$ or C $(26.1 \%$ and $27.2 \%)$, both being less effective at higher concentration (Table 6). A completely different trend was observed while testing $\mathrm{H}$ waste extract, able to stimulate cell proliferation and migration only at 5 $\mu \mathrm{L} / \mathrm{mL}$.
Figure 6 shows the migration of fibroblasts after scratch and culture with $1 \mu \mathrm{L} / \mathrm{mL}$ CLH extracts, being examples of the pooled waste extracts effect on wound healing $(\mathrm{CLH}, \mathrm{CL}, \mathrm{CH}, \mathrm{LH})$. Table 7 shows the effect of pooled waste extracts (CLH, CL, CH, LH) on fibroblasts migration and proliferation, as percentages of wound closure.

Cells cultured with $1 \mu \mathrm{L} / \mathrm{mL} \mathrm{CH}$ or $\mathrm{CLH}$ exhibited a complete wound closure within 48h, earlier than in control untreated cells. The wound healing stimulation was also observed when higher concentration of $\mathrm{CH}$ waste extracts $(5$ and $10 \mu \mathrm{L} / \mathrm{mL}$ ) were added to cells for $72 \mathrm{~h}$ (Table 7). 

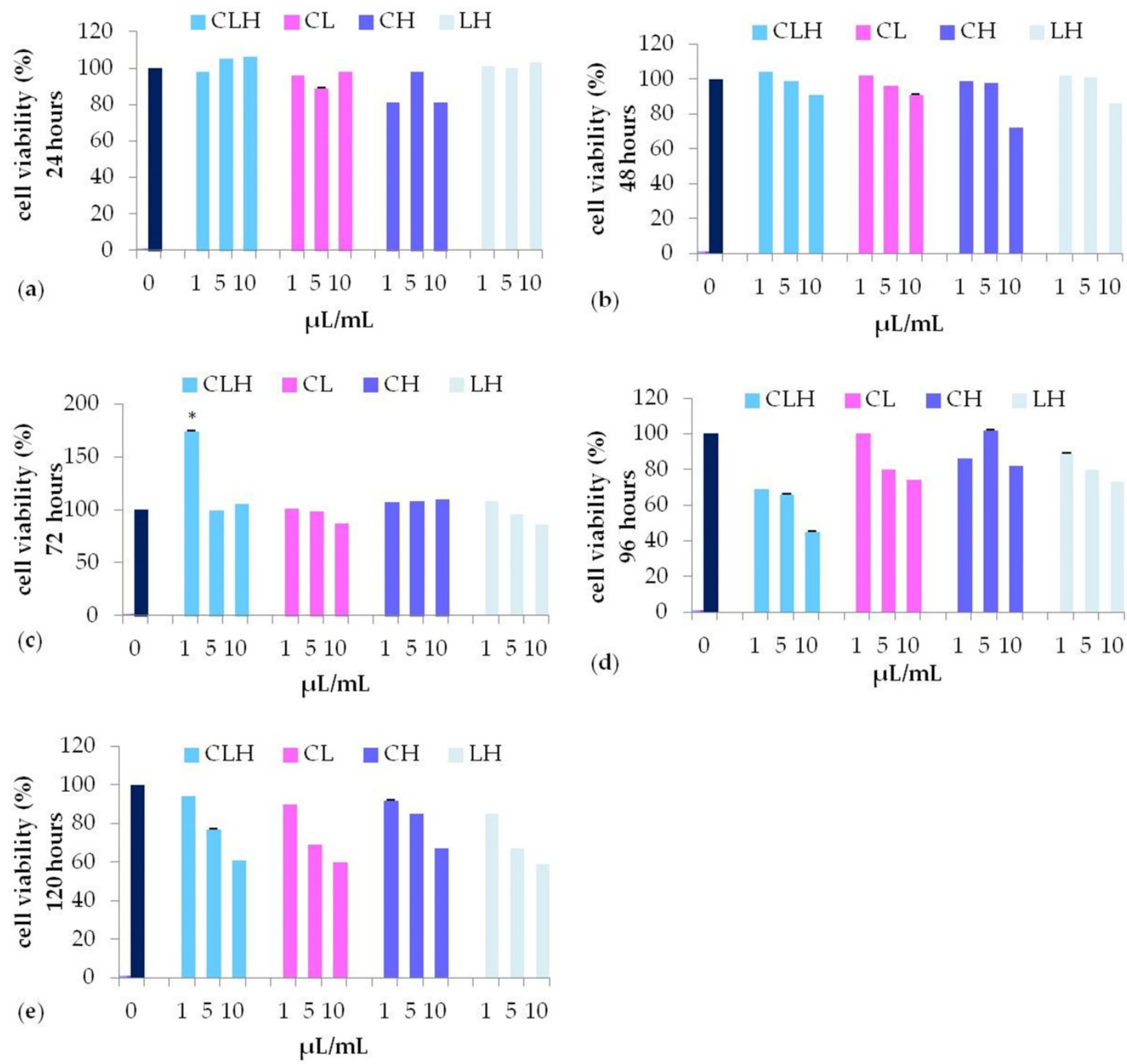

Figure 4. MTT assay of different concentration $(1,5,10 \mu \mathrm{L} / \mathrm{mL}$ ) of pooled waste extracts of $C$. arvensis, L. stoechas, and H. italicum CLH (light blue bar), $\mathrm{CL}$ (pink bar), $\mathrm{CH}$ (purple bar), LH (grey bar), after 24h (a), 48h (b), 72h (c), 96h (d) and 120h (e) (* $\mathrm{p}<0.05$ as compared to untreated control (0).

Table 7. Migration and proliferation of fibroblasts stimulated by pooled waste extracts

\begin{tabular}{|c|c|c|c|c|c|c|c|c|c|c|c|c|c|}
\hline \multirow[t]{2}{*}{ hours } & \multirow[t]{2}{*}{ Untreated } & \multicolumn{3}{|l|}{ CLH } & \multicolumn{3}{|l|}{ CL } & \multicolumn{3}{|l|}{$\mathrm{CH}$} & \multicolumn{3}{|l|}{ LH } \\
\hline & & $1 \mu \mathrm{L} / \mathrm{mL}$ & $5 \mu \mathrm{L} / \mathrm{mL}$ & $10 \mu \mathrm{L} / \mathrm{mL}$ & $1 \mu \mathrm{L} / \mathrm{mL}$ & $5 \mu \mathrm{L} / \mathrm{mL}$ & $10 \mu \mathrm{L} / \mathrm{mL}$ & $1 \mu \mathrm{L} / \mathrm{mL}$ & $5 \mu \mathrm{L} / \mathrm{mL}$ & $10 \mu \mathrm{L} / \mathrm{mL}$ & $1 \mu \mathrm{L} / \mathrm{mL}$ & $5 \mu \mathrm{L} / \mathrm{mL}$ & $10 \mu \mathrm{L} / \mathrm{mL}$ \\
\hline 24 & $24.9 \pm 1.8$ & $27.6 \pm 1.6$ & $21.7 \pm 2.7$ & $19.5 \pm 4.2$ & $24.2 \pm 3.8$ & $18.4 \pm 3.1$ & $14.1 \pm 1.9$ & $23.8 \pm 2.0$ & $20.8 \pm 2.4$ & $17.6 \pm 2.4$ & $24.7 \pm 1.3$ & $20.8 \pm 2.4$ & $18.6 \pm 1.5$ \\
\hline 48 & $30.6 \pm 2.1$ & $31.0 \pm 0.0$ & $29.2 \pm 0.9$ & $27.2 \pm 2.5$ & $29.8 \pm 0.8$ & $27.4 \pm 1.9$ & $22.6 \pm 2.2$ & $30.6 \pm 0.0$ & $32.1 \pm 0.6$ & $30.0 \pm 1.5$ & $30.9 \pm 0.7$ & $28.0 \pm 0.9$ & $24.2 \pm 1.9$ \\
\hline 72 & $31.8 \pm 0.0$ & closed & $31.2 \pm 0.0$ & $32.3 \pm 1.7$ & $30.4 \pm 0.0$ & $30.1 \pm 0.2$ & $28.0 \pm 1.6$ & closed & $33.0 \pm 0.0$ & $32.6 \pm 0.0$ & $31.7 \pm 0.0$ & $30.2 \pm 0.2$ & $28.7 \pm 1.1$ \\
\hline
\end{tabular}

Data were expressed as wound closure percentage (\%) at different time points $(24,48,72$ hours) untreated and stimulated by pooled waste extracts of C. arvensis, L. stoechas and H. italicum (CLH, CL, CH, LH) at different concentration $(1,5,10 \mu \mathrm{L} / \mathrm{mL})$.

Furthermore, $1 \mu \mathrm{L} / \mathrm{mL} \mathrm{LH}$ waste extracts elicited an effect on wound healing starting from $48 \mathrm{~h}$.

Wound closure time was faster in cells exposed to the combination of extracts as compared to cells exposed to one single extract. Indeed a greater cell proliferation and wound closure can be observed after $24 \mathrm{~h}$ in cells exposed to the combination of extracts (CLH) (Figure 6, panel b).
Figure 7 shows the expression of collagen I and III in cells exposed to single waste extracts or pooled waste extracts, as compared to control untreated cells. Collagen deposition was higher in cells treated with the extracts than control cells, indicating a more efficient and rapid wound closure in the presence of the tested extracts. 
TO

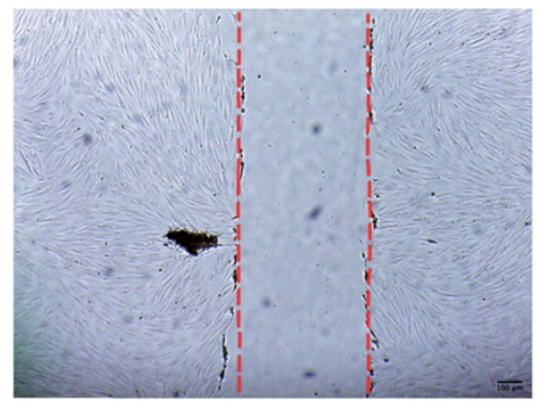

a)

T0

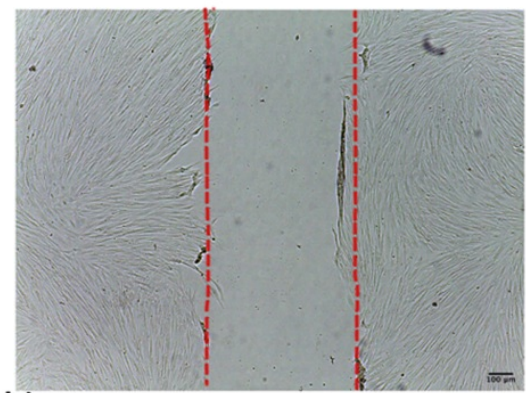

b)
$24 \mathrm{~h}$

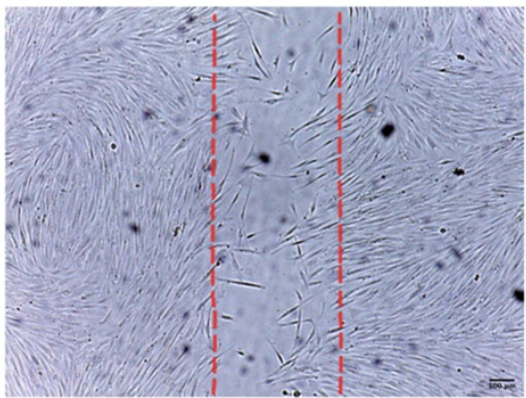

$24 \mathrm{~h}$

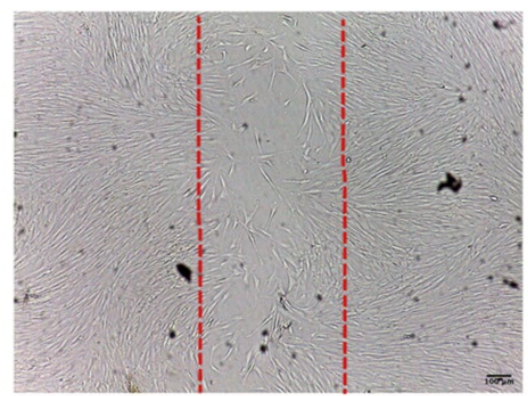

$48 \mathrm{~h}$

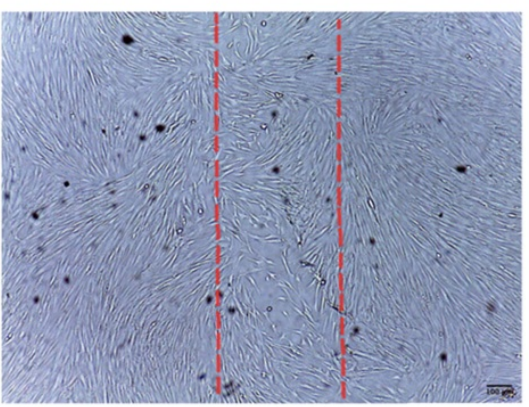

$48 \mathrm{~h}$

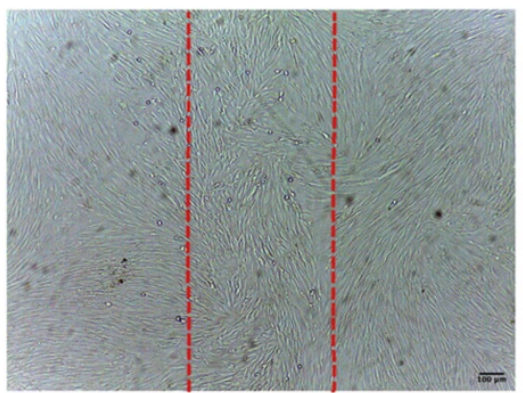

Figure 5. a) Migration of control cells after scratch. b) Migration of fibroblasts after scratch and treatment with $1 \mu \mathrm{L} / \mathrm{mL} \mathrm{L}$ extracts. Images are acquired by optical microscope and are examples of different independent experiments. Scale bar $=100 \mu \mathrm{m}$.

TO

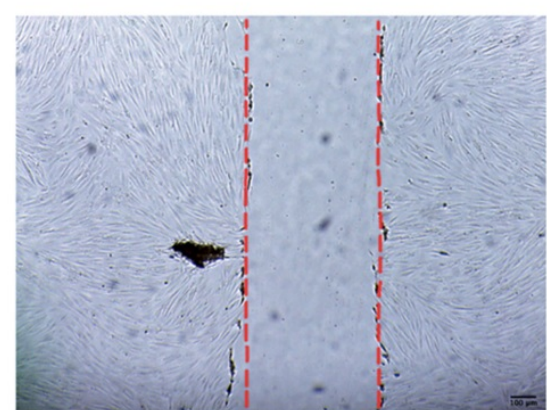

a)

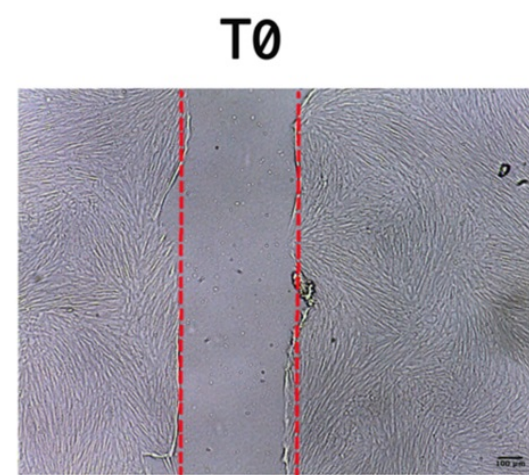

b)

Figure 6. a) Migration of control cells after scratch. b) Migration of fibroblasts after scratch and treatment with $1 \mu \mathrm{L} / \mathrm{mL} \mathrm{CLH}$ extracts. Images are acquired by optical microscope and are examples of different independent experiments. Scale bar $=100 \mu \mathrm{m}$.

\section{$24 \mathrm{~h}$}
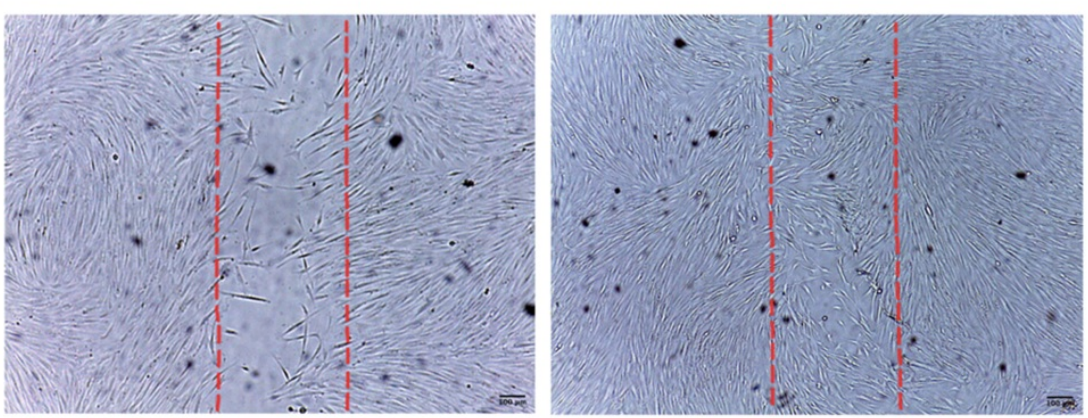

$48 \mathrm{~h}$
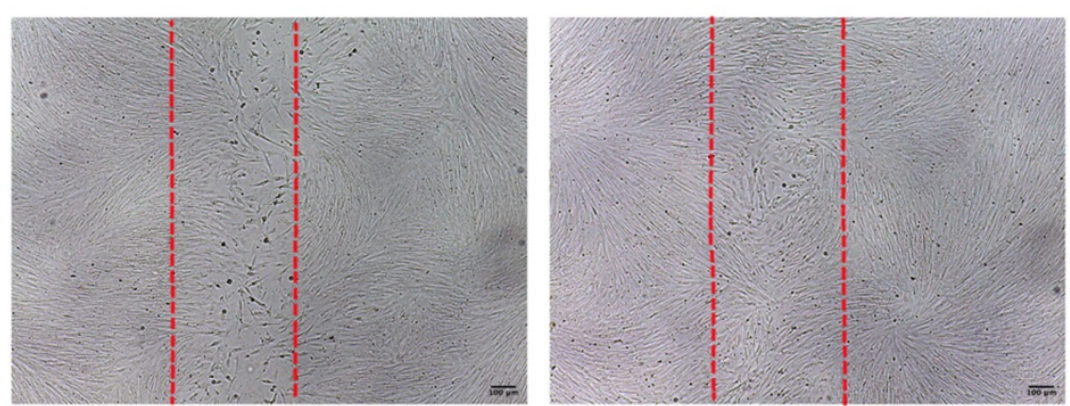


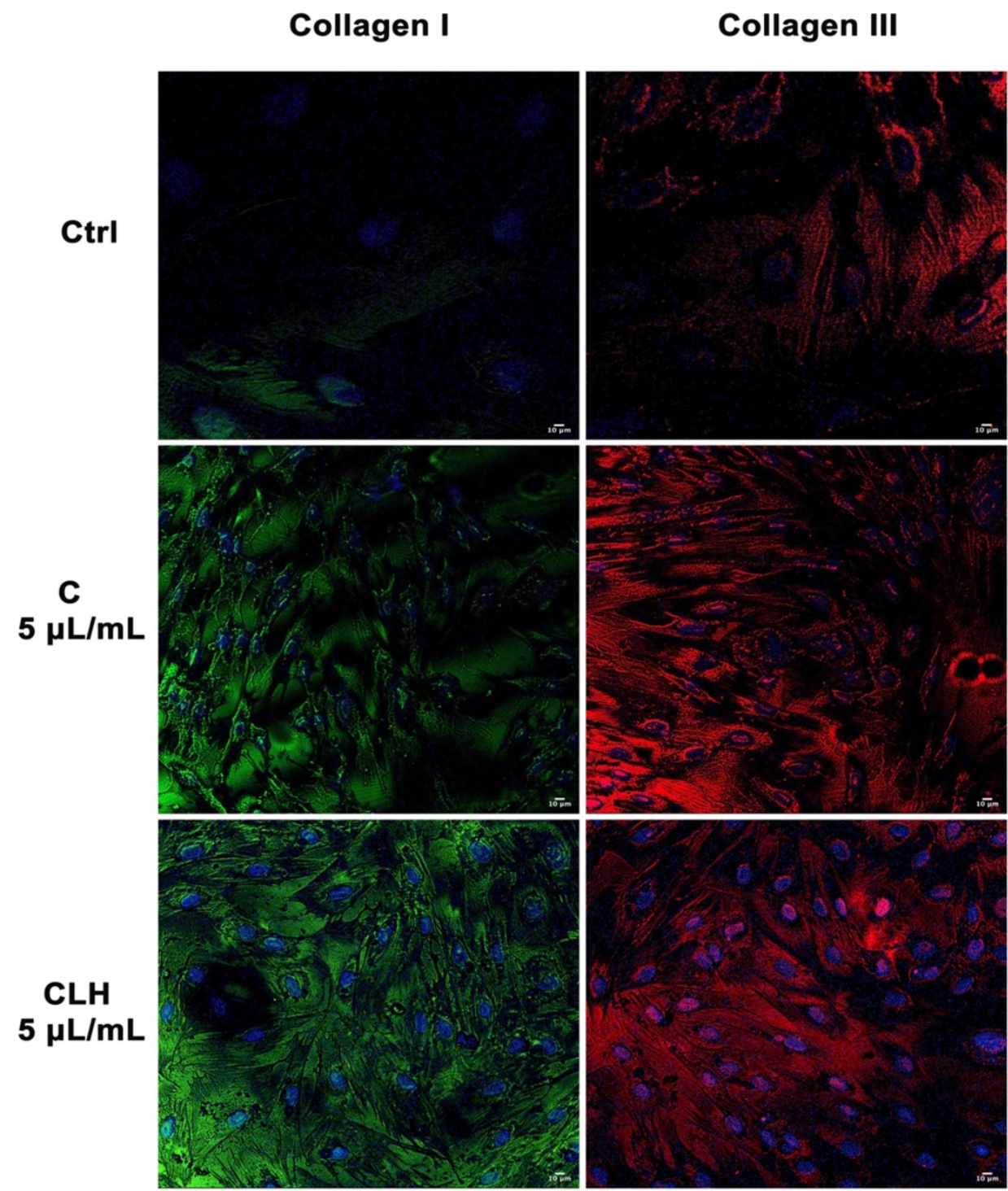

Figure 7. Analysis of collagen deposition during wound healing. Immunohistochemical analysis of the expression of Collagen type I and type III was assessed in fibroblasts after scratch and treatment with different concentrations of single waste extract $(\mathrm{C}, \mathrm{L}, \mathrm{H})$ or pooled waste extracts $(\mathrm{CLH}, \mathrm{CL}, \mathrm{CH}, \mathrm{LH})$ for 72 hours. Control cells were cultured in basic growing medium. Nuclei are labelled with 4,6-diamidino-2-phenylindole (DAPI, blue). Scale bars: $10 \mu \mathrm{m}$. The figures are representative of different independent experiments. For each differentiation marker, fields with the highest yield of positively stained cells are shown.

\section{Discussion}

Tissue regeneration is a quite complex process that consists in a sequence of cellular events leading to restore functionality. This reparative event involves cell migration, the deposition of collagen and the secretion of soluble mediators [35]. Fibroblasts play a crucial role in skin wound closure, from the early inflammatory phase to the final extracellular matrix production that is essential to restore physical barrier [36], [37]. Actually, plants and herbs, as active medicinal, are applied to stimulate stem cell proliferation, regeneration and rehabilitation in damaged tissues, being nowadays still employed in the attempt to counteract different groups of diseases [38]. Moreover, different natural compounds, as bioactive molecules are largely used in vitro to condition specific culturing media in the attempt to activate stem cell regenerative potential [39]-[42]. On the other hand, they have been also largely exploited in cancer treatment, for their capability to inhibit cell proliferation and neoplastic progression [43]-[46]. The use of plant extracts or plant-derived compounds are largely preferred because of their widespread availability, fewer side effects, and effectiveness as crude preparations [47][21]. Additionally, new green practices employ waste materials, after essential oil production from aromatic plants, with zero, or low-cost raw material prices. These waste-derived plant phenolics could be used as antioxidants in food products, pharmaceuticals, for a more sustainable approach on the whole plant [48], [49]. Moreover, the management of cutaneous wounds can be further elicited by the associated antioxidant activity of some 
plant extracts [22], [50], [51]. Components of traditional medicinal plants, as flavonoids, saponins, phenols, tannins and essential oils, are known for their antiseptic, anti-inflammatory, antioxidant properties, collagen synthesis stimulation and cell proliferative activities, biological processes deeply involved in wound healing [52]. Therefore phytochemical screening assay which is considered a simple, quick, and inexpensive procedure [53], was the basis of our studies. Total phenolic amounts, were significantly higher in waste extracts from $\mathrm{L}$ and $\mathrm{H}$ if measured up to $C$. Phenolic compounds are well-known molecules that have many biological properties, including antioxidant activity, that play an important role in wound healing by preventing and protecting oxidative damage from free radicals [54]. L and also $\mathrm{H}$ extracts exhibited a strong antioxidant activity, significantly higher $(\mathrm{P}<0.01)$ as compared to the effect elicited by $C$, along all the experimental time points of the ABTS assay (0-50 minutes, Figure 2 panel a). The positive Pearson correlation between antioxidant activity measured by ABTS and total phenolic contents, indicate that the antioxidant activity depends on the amount of the phenolic fraction, rosmarinic acid (L) and caffeoylquinic acid derivatives ( $\mathrm{H}$ and $\mathrm{C}$ ), confirming what previously showed by other authors [55]-[58]. Moreover, even though the amount of total phenolic amounts was similar in all the pooled wasted extracts $(\mathrm{CL}, \mathrm{CH}, \mathrm{LH}$, $\mathrm{CLH}), \mathrm{LH}$ waste extracts showed a better antioxidant activity, similar to the positive control (Trolox). We can hypothesize that this different effect could be explained by a different concentration of various compounds, as for example saponines, tannins, alkaloids, alkenyl phenols, glycoalkaloids, flavonoids, sesquiterpenes lactones, terpenoids and phorbol esters, previously described by other authors [59]. Interestingly, caffeoylquinic acid derivatives were the abundant phenol present in all the waste extracts except for CL in which rosmarinic acid was predominant. In LH the amount of caffeoylquinic acid derivatives was followed by rosmarinic acid, acting in a synergic manner to enhance the biological activity of the extracts [56], while in CL the antioxidant activity was mainly related to the presence of rosmarinic acid and rosmarinic acid derivatives. Among them some were previously described able to act synergistically by enhancing the bioactivity of each single compound [60]. Our results perfectly fit with the existing literature, which underlined the relationship between antioxidant activity, the presence of phenolic compounds and cell proliferation [52]. Nevertheless, our results highlight a further use of waste materials to ameliorate regenerative and antioxidant processes. Actually some authors described that extracts from L
[61] and C [62] exert a high inhibitory effect on cancer cell proliferation in vitro, without affecting healthy normal cells growing at low concentrations [45], showing a dual and opposite effect depending on the concentration and time of exposure to the plant extracts. At the same time, our waste extracts didn't exhibit any cytotoxic effects on cell proliferation, especially at low concentrations and for prolonged culturing time, both alone $(\mathrm{C}, \mathrm{L}, \mathrm{H})$ or as pooled waste extracts (CL, CH, LH, CLH). Our results confirm previous studies on aqueous extracts of the same plants, validating that waste material is still rich in bioactive compounds, [63]. In the present paper we describe for the first time stimulatory effects of waste extracts from leaves of $\mathrm{L}$, or $\mathrm{H}$. or $\mathrm{C}$ on fibroblast migration. Fibroblasts are known to play an essential role in wound healing, and cell migration is one of the most essential steps, during the proliferative phase, responsible for wound closure [1], [21], [64], [65]. Moreover, fibroblasts are involved in extracellular matrix synthesis, together with secretion of different growth factors as transforming growth factor (TGF- $\beta 1$ ) and basic fibroblast growth factor (b-FGF), able to induce hyaluronic acid secretion and matrix deposition [66]. Here we demonstrate that our extracts are able to induce Collagen I and III deposition during wound healing, thus accelerating the repairing process (Figure 7). The stimulation of fibroblast migration and proliferation, elicited by $\mathrm{L}$ and $\mathrm{C}$ waste extracts alone or the combination of $\mathrm{CH}$ and CLH pooled waste extracts; demonstrate that these compounds could contribute in the rebuilding of new granulation tissue thus restoring normal skin function. Our data further infer the use of postdistillation waste extracts to induce tissue remodeling stimulating anti-inflammatory responses and wound healing, as the aqueous extracts previously described by other authors [8][67]. Within this context, the waste extracts described here could be used in the future in different combination, to stimulate wound healing processes and antioxidant responses in damaged skin, thanks to their synergistic effect.

\section{Conclusions}

The data described in our study unravel a novel role of L. stoechas, H. italicum. and C. arvensis leaves waste extracts, and pooled combination of them, for the treatment of skin wounds. Taken together, our preliminary results demonstrate that waste extracts exhibit in vitro regenerative properties after environmental stress exposure and antioxidant activities related to the presence of phenolic compounds. Further in vitro and in vivo studies are needed to translate these results in future applications for tissue regeneration. 


\section{Acknowledgments}

We would like to thank FarmAsinara - Officine Cosmetiche dell'Asinara, for the support.

\section{Author contributions}

R.A, S.C, S.S, E.B and G.S performed the experiments; R.A and S.C performed data analysis, data curation and wrote the original draft; R.A, S.C and M.M reviewed and edited the manuscript and scientific literature; G.P validated the results and found resources; M.M supervised the research activity and article. All the authors approved the final version to be submitted.

\section{Competing Interests}

The authors have declared that no competing interest exists.

\section{References}

1. Barrientos S, Stojadinovic O, Golinko MS, et al. Growth factors and cytokines in wound healing. Wound Repair and Regeneration. 2008;(5):585-601.

2. Behm D, Colado JC. The effectiveness of resistance training using unstable surfaces and devices for rehabilitation. Int. J. Sports Phys. Ther. 2012;7(2):226-41.

3. Maddaluno L, Urwyler C, Werner S. Fibroblast growth factors: Key players in regeneration and tissue repair. Development (Cambridge). 2017;144(22):4047-4060.

4. Bainbridge P. Wound healing and the role of fibroblasts. J. Wound Care. 2013;22:407

5. Tracy LE, Minasian RA, Caterson EJ. Extracellular Matrix and Dermal Fibroblast Function in the Healing Wound. Advances in Wound Care. 2016;(3):119-136

6. Wong T., McGrath JA, Navsaria H. The role of fibroblasts in tissue engineering and regeneration. British Journal of Dermatology. 2007:156(6):1149-55.

7. Ebeling $\mathrm{S}$, et al. From a traditional medicinal plant to a rational drug: Understanding the clinically proven wound healing efficacy of birch bark extract. PLoS One, 2014;9(1):e86147.

8. Fronza M, Heinzmann B, Hamburger M, et al. Determination of the wound healing effect of Calendula extracts using the scratch assay with 3T3 fibroblasts. J. Ethnopharmacol. 2009;126(3):463-7.

9. Geetha S, Sai Ram M, Singh V, et al. Anti-oxidant and immunomodulatory properties of seabuckthorn (Hippophae rhamnoides) - An in vitro study. J. Ethnopharmacol., 2002;79: 373-378.

10. Sebai H, Selmi S, Rtibi K, et al. Lavender (Lavandula stoechas L.) essential oils attenuate hyperglycemia and protect against oxidative stress in alloxan-induced diabetic rats. Lipids Health Dis. 2013;12:189.

11. Siddiqui NA, Enezi MA Al, Alam P, et al. A novel acyclic diterpenic alcohol isolated from antioxidant active ethanol extract of leaves of centaurothamnus maximus grown in Saudi Arabia. African J. Tradit. Complement. Altern. Med. 2015;12(3):42-48

12. Mastelic J, Politeo O, Jerkovic I, et al. Composition and antimicrobial activity of Helichrysum italicum essential oil and its terpene and terpenoid fractions. Chem. Nat. Compd., 2005;41: 35-40.

13. Graf E. Hagers Handbuch der pharmazeutischen Praxis. Pharm. Unserer Zeit. 1991; 20(4): 186-187.

14. Grieve MM. A Modern Herbal. Botanical.com. 1995. Pages 919, ISBN: 0486227987 \& 0486227995.

15. Chevallier A. Encyclopedia of Medicinal Plants. Encycl. Med. Plants. 2001. ISBN-10: 0789467836.

16. Askin T. Potential Genotoxic and Cytotoxic Effects of Plant Extracts. A Compendium of Essays on Alternative Therapy. 2012. Edition: 1Chapter: 11.

17. Gamez MJ, Zarzuelo A, Risco S, et al. Hypoglycemic activity in various species of the genus Lavandula. Part 2: Lavandula dentata and Lavandula latifolia. Pharmazie. 1988;43(6):441-2.

18. Uysal $\mathrm{S}$, et al. In vitro antioxidant, cytotoxicity and chemical profile of different extracts from Acanthus hirsutus Boiss used in Anatolian folk medicine. Eur. J. Integr. Med. 2018;17:135-140.

19. Gilani $\mathrm{AH}$, et al. Ethnopharmacological evaluation of the anticonvulsant sedative and antispasmodic activities of Lavandula stoechas L. J. Ethnopharmacol. 2000;71(1-2):161-7.

20. Miraj S. Lavandula stoechas l: A systematic review of medicinal and molecular perspectives. Der Pharm. Lett. 2016;5(6):170-179.
21. Vittorazzi C, Endringer DC, De Andrade TU, et al. Antioxidant, antimicrobial and wound healing properties of Struthanthus vulgaris. Pharm. Biol. 2016;54(2):331-7.

22. Annan K, Houghton PJ. Antibacterial, antioxidant and fibroblast growth stimulation of aqueous extracts of Ficus asperifolia Miq. and Gossypium arboreum L., wound-healing plants of Ghana. J. Ethnopharmacol. 2008;119(1):141-144.

23. Houghton PJ, Hylands PJ, Mensah AY, et al. In vitro tests and ethnopharmacological investigations: Wound healing as an example. Journal of Ethnopharmacology. 2005;100(1-2):100-7.

24. Dayem AA, et al. The role of reactive oxygen species (ROS) in the biological activities of metallic nanoparticles. IJMS. 2017;18(1): 120.

25. Božin BN, Lakić NS, Mišan A, et al. Phenolic profile, antioxidant and antimicrobial activity of oregano (Origanum vulgare L, Lamiaceae) postdistillation waste extracts. CEFood 2012 - Proceedings of 6th Central European Congress on Food. 2012;40(2):809-816.

26. Peev G, Penchev P, Peshev D, et al. Solvent extraction of rosmarinic acid from lemon balm and concentration of extracts by nanofiltration: Effect of plant pre-treatment by supercritical carbon dioxide. Chem. Eng. Res. Des. 2011;89(11):2236-2243.

27. Džamić AM, et al. Composition, antifungal and antioxidant properties of Hyssopus officinalis L. subsp. pilifer (Pant.) Murb. essential oil and deodorized extracts. Ind. Crops Prod. 2013;51:401-407.

28. Gavarić N, et al. Postdistillation waste material of thyme (Thymus vulgaris L., Lamiaceae) as a potential source of biologically active compounds. Ind. Crops Prod. 2015;74:457-464.

29. Navarrete A, Herrero M, Martín A, et al. Valorization of solid wastes from essential oil industry. J. Food Eng. 2011:104(2):196-201.

30. Vladić J, Zeković Z, Jokić S, et al. Winter savory: Supercritical carbon dioxide extraction and mathematical modeling of extraction process. J. Supercrit. Fluids. 2016;117:89-97.

31. Aslam MS, Syarhabil MA, Mamat AS. "Phytochemical Evaluation of Polyherbal Formulation of Clinacanthus nutans and Elephantopus scaber to Identify Flavonoids. Pharmacogn. J. 2016. 8(6):534-541.

32. Maldini $\mathrm{M}$, et al. A new approach to discriminate Rosmarinus officinalis $\mathrm{L}$. plants with antioxidant activity, based on HPTLC fingerprint and targeted phenolic analysis combined with PCA. Ind. Crops Prod. 2016;94:665-672.

33. Sarais G, D'Urso G, Lai C, et al. Targeted and untargeted mass spectrometric approaches in discrimination between Myrtus communis cultivars from Sardinia region. J. Mass Spectrom. 2016;51(9):704-15.

34. Petretto GL, et al. Variability of chemical composition and antioxidant activity of essential oils between Myrtus communis var. Leucocarpa DC and var. Melanocarpa DC. Food Chem. 2016;197: 124-131.

35. Gonzalez ACDO, Andrade ZDA, Costa TF, et al. Wound healing - A literature review. Anais Brasileiros de Dermatologia. 2016; 91(5): 614-620.

36. Landén NX, Li D, Ståhle M. Transition from inflammation to proliferation: a critical step during wound healing. Cellular and Molecular Life Sciences. 2016;73(20):3861-85

37. Werner S, Krieg T, Smola H. Keratinocyte-fibroblast interactions in wound healing. J. Invest. Dermatol. 2007;127(5):998-1008.

38. Cragg GM, Newman DJ. Natural products: A continuing source of novel drug leads. Biochimica et Biophysica Acta - General Subjects. 2013;1830(6):3670-95.

39. Basoli V, et al. Melatonin and vitamin D interfere with the adipogenic fate of adipose-derived stem cells. Int. J. Mol. Sci. 2017; 18:981.

40. Maioli M, et al. Osteogenesis from Dental Pulp Derived Stem Cells: A Novel Conditioned Medium Including Melatonin within a Mixture of Hyaluronic, Butyric, and Retinoic Acids. Stem Cells Int. 2016;:1-8.

41. Maioli $\mathrm{M}$, et al. Amniotic fluid stem cells morph into a cardiovascular lineage: Analysis of a chemically induced cardiac and vascular commitment. Drug Des. Devel. Ther. 2013;7:1063-1073.

42. Maioli $\mathrm{M}$, et al. Hyaluronan esters drive smad gene expression and signaling enhancing cardiogenesis in mouse embryonic and human mesenchymal stem cells. PLoS One. 2010;5:11.

43. Pant B. Application of plant cell and tissue culture for the production of phytochemicals in medicinal plants. Adv. Exp. Med. Biol. 2014;808:25-39.

44. Van Slambrouck $S$, et al. Effects of crude aqueous medicinal plant extracts on growth and invasion of breast cancer cells. Oncol. Rep. 2007;17(6):1487-92.

45. Maioli M, et al. Synthesis of magnolol and honokiol derivatives and their effect against hepatocarcinoma cells. PLoS One. 2018:13:2

46. Ferhi S, et al. Total Phenols from Grape Leaves Counteract Cell Proliferation and Modulate Apoptosis-Related Gene Expression in MCF-7 and HepG2 Human Cancer Cell Lines. Mol. 2019;24(3):612.

47. Agyare C, Amuah E, Adarkwa-Yiadom M, et al. Medicinal plants used for treatment of wounds and skin infections: Assessment of wound healing and antimicrobial properties of malootus oppositifolius and Momordcca Chiarantia. Int. J. Phytomedicine. 2014:6(1):50-58.

48. Cruciani S, et al. Myrtus Polyphenols, from Antioxidants to Anti-Inflammatory Molecules: Exploring a Network Involving Cytochromes P450 and Vitamin D. Molecules. 2019;24(8):1515.

49. Cruciani S, et al. Extracts from Myrtle Liqueur Processing Waste Modulate Stem Cells Pluripotency under Stressing Conditions. Biomed Res. Int. 2019;(6):1-12.

50. Süntar I, Akkol EK, Nahar L, et al. Wound healing and antioxidant properties: do they coexist in plants?. Free Radicals Antioxidants. 2012;121(12):804-810. 
51. Weng A, Thakur, Melzig, et al. Chemistry and pharmacology of saponins: special focus on cytotoxic properties. Bot. Targets Ther. 2011;1:19-29.

52. Bahramsoltani R, Farzaei MH, Rahimi R. Medicinal plants and their natural components as future drugs for the treatment of burn wounds: An integrative review. Archives of Dermatological Research. 2014;306(7):601-17.

53. Sasidharan S, Chen Y, Saravanan D, et al. Extraction, isolation and characterization of bioactive compounds from plants' extracts. African J. Tradit. Complement. Altern. Med. 2011;8(1):1-10.

54. Matos F, et al. Antioxidant capacity of the essential oils from lavandula luisieri, l. Stoechas subsp. Lusitanica, l. Stoechas subsp. Lusitanica $x$ l. Luisieri and 1. Viridis grown in algarve (portugal). J Essent Oil Res. 2009;21(4):327-336.

55. Erkan N, Ayranci G, Ayranci E. Antioxidant activities of rosemary (Rosmarinus Officinalis L.) extract, blackseed (Nigella sativa L.) essential oil, carnosic acid, rosmarinic acid and sesamol. Food Chem. 2008;110(1):76-82.

56. Fraisse D, Felgines C, Texier O, et al. Caffeoyl Derivatives: Major Antioxidant Compounds of Some Wild Herbs of the Asteraceae Family. Food Nutr. Sci. 2011;2(03).

57. Wang H, Provan GJ, Helliwell K. Determination of rosmarinic acid and caffeic acid in aromatic herbs by HPLC. Food Chem. 2004;87(2): 307-311.

58. Park SU, Uddin MR, Xu H, et al. Biotechnological applications for rosmarinic acid production in plant. African Journal of Biotechnology. 2008;7(25):4959-4965.

59. Abdallah EM. Plants: An alternative source for antimicrobials. J. Appl. Pharm. Sci. 2011;01(06): 16-20.

60. Tiwari S. Plants: A Rich Source of Herbal Medicine. J. Nat. Prod. 2008;1:27-35.

61. Yilmaz MI, et al. Effect of antihypertensive agents on plasma adiponectin levels in hypertensive patients with metabolic syndrome. Nephrology. 2007;2(2):147-53.

62. Barajas-Farias LM, et al. A dual and opposite effect of Calendula officinalis flower extract: Chemoprotector and promoter in a rat hepatocarcinogenesis model. Planta Med. 2006;72(3):217-221.

63. Rosa A, et al. Evaluation of the antioxidant and cytotoxic activity of arzanol, a prenylated a-pyrone-phloroglucinol etherodimer from Helichrysum italicum subsp. Microphyllum. Chem. Biol. Interact. 2007;165(2):117-26.

64. Reinke JM, Sorg H. Wound repair and regeneration. European Surgical Research. 2012;49:1.

65 Eming SA, Martin P, Tomic-Canic M. Wound repair and regeneration: Mechanisms, signaling, and translation. Science Translational Medicine. 2014;6(265):265sr6.

66. Price RD, Myers S, Leigh IM, et al. The Role of Hyaluronic Acid in Wound Healing. Am. J. Clin. Dermatol. 2005;6(6):393-402AJ.

67. Lee H, Hong Y, Kwon SH, et al. Anti-aging effects of Piper cambodianum P. Fourn. extract on normal human dermal fibroblast cells and a wound-healing model in mice. Clin Interv Aging. 2016;11:1017-26. 